\title{
Początki Duszpasterstwa Akademickiego w Białymstoku i jego pierwsi duszpasterze
}

W Poznaniu, 18 listopada 1945 roku, odbył się pierwszy po II wojnie światowej zjazd duszpasterzy akademickich, a w 1946 roku Episkopat Polski podjął decyzję, że Duszpasterstwa Akademickie będą funkcjonować jako odrębna instytucja kościelna. 9 maja 1953 roku powstała Komisja Krajowa Duszpasterstwa Akademickiego, której zadaniem było koordynowanie pracy duszpasterskiej w środowisku akademickim w całej Polsce ${ }^{1}$. W tym samym dniu władze kościelne zatwierdziły „Wytyczne Episkopatu dla Duszpasterstwa Akademickiego”2. Na Konferencji Episkopatu Polski w Krakowie Prymas Polski kard. Stefan Wyszyński wezwał władze diecezjalne do powołania we wszystkich miastach akademickich duszpasterzy do pracy ze studentami w ramach specjalnego typu duszpasterzowania, jakim było Duszpasterstwo Akademickie ${ }^{3}$. Biskupi zatwierdzając „Wytyczne” pracy Duszpasterstwa Akademickiego stwierdzali, że „Duszpasterstwo Akademickie jest urzędem kościelnym, powoływanym przez ordynariusza”. „Wytyczne” zostały uzupełnione w 1967 roku; powstał wówczas „Regulamin Duszpasterstwa Akademickiego"4, a w 1971 roku „Statut Duszpasterstwa Akademickiego”.

9 maja 1953 roku na Konferencji Plenarnej Episkopatu Polski podano również najważniejsze informacje dotyczące Duszpasterstwa Akademickiego. W każdej diecezji Duszpasterstwo Akademickie było urzędem kościelnym erygowanym przez ordynariusza w myśl kan. 100 Corpus Iuris Canonici (CIC) i jako takie posiadało osobowość prawną. Celem Duszpasterstwa Akademickiego było prowadzenie zorganizowanej opieki duchownej nad całą społecznością akademicką. Głównym ośrodkiem pracy duszpasterskiej miał być kościół akademicki, przy którym, o ile istniały takie możliwości, miał rezydować duszpasterz akademicki. Środki na potrzeby Duszpasterstwa miał zapewnić ordynariusz diecezji $\mathrm{w}$ porozumieniu z duszpasterzem akademickim.

S. A. Bogaczewicz, K. Jarkiewicz, Duszpasterstwo akademickie w Polsce po II wojnie światowej, „Biuletyn Instytutu Pamięci Narodowej" 2001, nr 10, s. 43.

2 Archiwum Archidiecezjalne w Białymstoku (dalej: AAB), Teczka: Duszpasterstwo Akademickie (dalej: TDA), Wytyczne pracy Duszpasterstwa Akademickiego przyjęte na Konferencji Plenarnej Episkopatu Polski 9 maja 1953 r., mps.

3 "Oaza wolności". Duszpasterstwo akademickie w latach siedemdziesiątych XX w. Materiały pokonferencyjne, red. M. Marcinkiewicz, Szczecin 2011, s. 131.

4 AAB, TDA, Regulamin Komisji Episkopatu Polski Duszpasterstwa Akademickiego, Warszawa 24.XI.1967 r., mps. 
Duszpasterza akademickiego mianował i odwoływał ordynariusz miejsca; jeśli był zakonnikiem to w porozumieniu z władzami zakonnymi. Duszpasterz podlegał bezpośrednio i całkowicie ordynariuszowi miejsca. Przed nim był odpowiedzialny za całokształt swej pracy, z której miał składać okresowe sprawozdania.

Do obowiązków duszpasterza należało: zapewnienie społeczności akademickiej życia liturgicznego i sakramentalnego; urządzanie rekolekcji otwartych i zamkniętych oraz dni skupienia dla młodzieży akademickiej, pracowników naukowych i administracyjnych uczelni; dbanie o pogłębienie wiedzy religijnej młodzieży akademickiej przez organizowanie odczytów, kursów, wykładów, konferencji, spotkań dyskusyjnych; wychowanie etyczne młodzieży; opieka moralna nad domami i internatami akademickimi; urządzanie bibliotek i czytelni; dokonywanie przewidzianych w prawie kościelnym i praktyce duszpasterskiej Kościoła odwiedzin pasterskich członków społeczności akademickiej oraz organizowanie w granicach możliwości pomocy charytatywnej dla potrzebującej młodzieży.

Kwestią uposażenia duszpasterza akademickiego miał się zająć ordynariusz diecezji.

Do pomocy duszpasterza akademickiego mogli być powołani jego współpracownicy spośród miejscowego duchowieństwa. Duszpasterz akademicki miał także obowiązek prowadzenia kancelarii kościoła akademickiego ${ }^{5}$.

Dla usprawnienia prac Duszpasterstwa Akademickiego w Polsce Episkopat wyznaczył swego biskupa - delegata. Został nim bp dr Zdzisław Goliński, biskup częstochowski. To on organizował ogólnopolskie spotkania duszpasterzy akademickich w celu pogłębienia ich życia wewnętrznego oraz omówienia prac duszpasterskich.

Zostały też wydane dość szczegółowe wytyczne dla duszpasterza akademickiego ${ }^{6}$. Do jego obowiązków należała systematyczna troska o swe życie wewnętrzne, gdyż było to wyrazem jego gorliwej i owocnej pracy nad społecznością akademicką. Miał dbać o stałe doskonalenie znajomości środowiska, w którym pracował, by zaradzać jego potrzebom; sumiennie wypełniać swe kapłańskie obowiązki w konfesjonale, na ambonie, podczas rozmów duszpasterskich. Miał wyznaczone stałe godziny przyjęć w kancelarii kościoła akademickiego. Odbywał wizyty duszpasterskie, odwiedzał domy i internaty akademickie w miarę możliwości i okoliczności. Szczególną troską miał otoczyć chorujących i pozostających w trudnej sytuacji materialnej akademików. Czas przyjęć i ogólny terminarz spotkań duszpasterskich miał być podany do ogólnej wiadomości społeczności akademickiej danego miasta.

Z początkiem każdego roku akademickiego nawiązywał kontakt z ordynariuszem miejsca i ustalał termin oraz program nabożeństwa inaugurującego nowy rok akademicki. Jako roztropny wychowawca był przezorny i roztropny,

AAB, TDA, Wytyczne pracy Duszpasterstwa Akademickiego przyjęte na Konferencji Plenarnej Episkopatu Polski 9 maja 1953 r., mps.

6 AAB, TDA, Wytyczne dla duszpasterza akademickiego przyjęte na Konferencji Episkopatu w Krakowie 9 maja 1953 r., mps. 
z ojcowską troską i oddaniem służył młodzieży akademickiej. Stosunki duszpasterza akademickiego z gronem profesorskim danej uczelni wyższej i z młodzieżą akademicką miały być nacechowane miłością i serdecznością, ale też powagą odpowiednią do piastowanej godności.

Duszpasterstwo Akademickie w Białymstoku rozwijało się w ramach prawa kanonicznego o duszpasterstwie ogólnym, zgodnie z kan. 1373 § 2 CIC.

Za życia abp. Romualda Jałbrzykowskiego (zm. 1955 r.), Metropolity Wileńskiego, przebywającego w Białymstoku po zakończeniu II wojny światowej, to on był głównym duszpasterzem wszystkich form duszpasterzowania. Sytuacja w Polsce w okresie stalinizmu uniemożliwiała wydzielenie specjalnej instytucji do spraw Duszpasterstwa Akademickiego.

Księża przy poszczególnych świątyniach Białegostoku działali w ramach swych kompetencji, a ks. Witold Pietkun był delegatem Arcybiskupa do poszczególnych spraw akademickich, jak na przykład rekolekcje, odprawy Kolegium duszpasterzy akademickich, czy ogólnopolskie konferencje.

Od początku funkcjonowania Duszpasterstwa Akademickiego w Białymstoku zdarzały się spięcia z władzami państwowymi, czy organizacjami politycznymi. Wszechwładny wówczas Związek Młodzieży Polskiej podjął próbę usunięcia z Akademii Medycznej w Białymstoku uczestników rekolekcyjnej konferencji w kościele św. Wojciecha, a jeden z wykładowców „rozdzierał swe szaty" na wykładach ubolewając nad ciemnotą młodzieży.

W myśl kanonu 1373 § 2 CIC abp Jałbrzykowski w marcu 1954 roku polecił ks. W. Pietkunowi zaprosić księży z każdego ośrodka parafialnego i każdego kościoła rektoralnego w Białymstoku do Kolegium Duszpasterzy Akademickich. Z woli arcypasterza w skład Kolegium weszli wówczas: ks. Piotr Boryk, ks. Edward Kisiel, ks. Maciej Pawlik, ks. Jan Zabański, oraz na zasadzie współpracownika ks. Jan Trochim. Pierwsze posiedzenie Kolegium Duszpasterzy Akademickich miało miejsce w gabinecie abp. Jałbrzykowskiego 23 marca 1954 roku. Ksiądz Aleksander Syczewski, rektor kościoła pw. Najświętszego Serca Pana Jezusa, uczestniczył w zebraniu Kolegium tylko raz. Członkowie tego gremium spełniali swe obowiązki w Duszpasterstwie Akademickim na podstawie nominacji ordynariusza. Kanon Kodeksu Kanonicznego uzależniał pracę duszpasterską na tym odcinku od szczególnych, osobistych kwalifikacji i predyspozycji poszczególnych kapłanów.

W skład Kolegium Duszpasterzy Akademickich weszli więc kapłani pracujący przy poszczególnych świątyniach Białegostoku. Działalność Kolegium zależała bezpośrednio od Arcybiskupa i podlegała jego kontroli i nadzorowi.

Taka zespołowa forma organizacji Duszpasterstwa Akademickiego w Białymstoku wymagała koordynacji. Metropolita Jałbrzykowski każdorazowo zlecał ks. Pietkunowi kierownictwo nad pracami Kolegium, jak i mobilizował księży do prac duszpasterskich na rzecz młodzieży akademickiej i środowisk uczelnianych. Zakres pracy pokrywał się częściowo z obowiązkami, jakie pełnił 
ks. Pietkun w Kurii Arcybiskupiej, w referacie duszpasterskim. Spełnianie przez niego obowiązków w Duszpasterstwie Akademickim nie wymagało koordynacji z władzami administracji cywilnej, gdyż ks. Pietkun nie był mianowany do żadnego duszpasterstwa parafialnego, jak inni członkowie Kolegium. Według ks. Pietkuna nie istniała więc potrzeba dokonywania formalności u władz państwowych z tytułu dekretu o obsadzaniu stanowisk kościelnych ${ }^{7}$.

Pierwsze miesiące działalności Duszpasterstwa Akademickiego w Białymstoku polegały między innymi na skoncentrowaniu pracy duszpasterskiej przy kościele pw. Wniebowzięcia Najświętszej Maryi Panny w Białymstoku, choć oczekiwano na przekazanie lub wybudowanie osobnej świątyni na potrzeby Duszpasterstwa. Brak jednak takowej nie wpłynął negatywnie na rozwój pracy duszpasterskiej, chociaż ośrodek parafialny przy prokatedrze był przeciążony rozmaitymi innymi obowiązkami parafialnymi do tego stopnia, że praktycznie nikomu z księży nie pozostawało wiele czasu na posługę w Duszpasterstwie Akademickim. Przy tej świątyni skupiało się około 90\% młodzieży akademickiej i personelu uczelni wyższych. Ksiądz Pietkun sugerował, by do prokatedry mianować księdza $\mathrm{z}$ wyraźnym obowiązkiem zaangażowania się $\mathrm{w}$ działalność Duszpasterstwa Akademickiego, przy jednoczesnym zwolnieniu go z innych obowiązków parafialnych. Sugerował, iż mógłby to być wracający ze studiów z Katolickiego Uniwersytetu Lubelskiego ks. Stanisław Piotrowski.

Pierwsze rekolekcje akademickie w Białymstoku odbyły się w dniach 21-25 marca 1954 roku przy frekwencji ponad 2 tys. osób. Organizowano też comiesięczne konferencje z zakresu wiedzy religijnej.

Koszty związane z działalnością Duszpasterstwa Akademickiego i ze świadczeniami charytatywnymi $\mathrm{w}$ ramach jego działalności pokrywano pierwotnie z ofiar składanych na tacę podczas Mszy św. wieczornej w każdą pierwszą niedzielę miesiąca. Proboszcz prokatedry, ks. Stanisław Urban, prawo „dysponowania tacą" przekazał Kolegium Duszpasterzy Akademickich, ale kosztami pierwszych rekolekcji akademickich w Białymstoku obciążył własną parafię pw. Wniebowzięcia Najświętszej Maryi Panny.

Mimo że w pierwszych tygodniach działalności Duszpasterstwa Akademickiego w Białymstoku kwestie Duszpasterstwa nie były wnoszone na porządek obrad konferencji dekanalnej, to jednak dziekan białostocki, ks. Kazimierz Borżym był na bieżąco informowany o jego warunkach pracy.

Ksiądz Pietkun widział konieczność wydania przez władzę diecezjalną regulaminu dla Duszpasterstwa Akademickiego oraz instrukcji dla księży wynikających z kan. 1373 § 2 CIC, gdzie należało uwzględnić obowiązki kapłanów należących do Kolegium Duszpasterzy Akademickich, by była podstawa do proporcjonalnego dzielenia innych zajęć parafialnych. Często bowiem działalność duszpasterska w Duszpasterstwie Akademickim rozbijała się o nadmiar innych prac, szczególnie katechezy, w poszczególnych parafiach. Wyrażał życzenie, by

Ibidem. 
przy każdej świątyni istniała odrębna tablica informująca o działalności Duszpasterstwa Akademickiego, podająca terminy i miejsce spotkań oraz nazwisko kapłana zajmującego się młodzieżą akademicką ${ }^{8}$.

Ksiądz Edward Kisiel, ówczesny sekretarz grona Kolegium Duszpasterzy Akademickich, 13 maja 1955 roku przesłał do Kurii Arcybiskupiej w Białymstoku pismo, w którym informował o zahamowaniu działalności Duszpasterstwa w marcu 1955 roku, gdyż dotychczasowy przewodniczący Kolegium ks. Witold Pietkun przestał pełnić swoją funkcję tłumacząc się, że nie ma do tego upoważnienia władzy kościelnej. W związku z tym sytuacja pozostałych członków Kolegium stała się niejasna. 5 czerwca 1955 roku zaplanowana była w prokatedrze konferencja akademicka, a na kilka tygodni przed terminem nie wiadomo było, kto miał ją przygotować i wygłosić9

Po śmierci abp. Jałbrzykowskiego (19 czerwca 1955 r.) działalność Duszpasterstwa Akademickiego została określona wytycznymi statutowymi ułożonymi na polecenie wikariusza kapitulnego ks. Adama Sawickiego. Odbyło się zebranie proboszczów miasta i terenowych duszpasterzy akademickich, na którym poprzez głosowanie wyrażono votum zaufania wobec osoby ks. Witolda Pietkuna. Polecono mu w dalszym ciągu koordynację pracy w Duszpasterstwie Akademickim. I choć jego kompetencje formalnie ustały, faktycznie działał poprzez osobisty kontakt z poszczególnymi księżmi terenowymi.

W lutym 1956 roku władze państwowe wystąpiły przeciwko ks. Pietkunowi, jako ówczesnemu wykładowcy w Archidiecezjalnym Wyższym Seminarium Duchownym, z represjami prawnymi. Od początków swego pobytu na Białostocczyźnie kapłan ten był „na cenzurowanym” u władz państwowych, szczególnie u służb bezpieczeństwa. Ksiądz Pietkun w marcu 1945 roku przyjechał do Polski, opuszczając Wilno. Został wykładowcą Seminarium Duchownego w Białymstoku. Już od pierwszych dni swego pobytu w Polsce Ludowej był inwigilowany przez Urząd Bezpieczeństwa. W lipcu 1945 roku został aresztowany przez funkcjonariuszy Wojewódzkiego Urzędu Bezpieczeństwa Publicznego w Białymstoku za kazanie w czasie procesji Bożego Ciała. Osadzony został w zakładzie karnym, ale zwolniono go na mocy amnestii. Przez kilka kolejnych lat przebywał w Łodzi, gdzie również wykładał w Seminarium Duchownym. W 1952 roku pozbawiony został przez władze prawa do wykładania na Wydziale Teologicznym Uniwersytetu Warszawskiego, za „wykorzystywanie katedry do głoszenia wiadomości i nauk przeciwnych zasadom ustrojowym Państwa”. 15 września 1952 roku ponownie został wykładowcą w białostockim Seminarium Duchownym, ale 1 lutego 1956 roku został usunięty z tego stanowiska za głoszenie patriotycznych kazań ${ }^{10}$.

AAB, TDA, Pismo ks. W. Pietkuna do Kurii Metropolitalnej w Białymstoku w sprawie Duszpasterstwa Akademickiego, z 4.III.1955 r.

9 AAB, TDA, Pismo ks. E. Kisiela do Kurii Arcybiskupiej w Białymstoku, z d. 13.V.1955 r.

10 T. Danilecki, Witold Pietkun, [w:] Encyklopedia Solidarności; dostęp 18.V.2019 r., http:/ / www.encysol. pl/wiki/Witold_Pietkun 
Na początku roku akademickiego 1955 / 1956 powstały kolejne wytyczne dotyczące działalności Duszpasterstwa Akademickiego w Białymstoku. Przewodniczącego Kolegium nazwano w tym projekcie koordynatorem. Miał on być wyznaczany przez Kurię Arcybiskupią. Do jego kompetencji należały sprawy ogólne w Duszpasterstwie Akademickim. Duszpasterze terenowi mieli kierować pracami swojej placówki z uwzględnieniem wytycznych od koordynatora oraz po uzgodnieniu z właściwym proboszczem lub rektorem kościoła. Koordynator ustalał tematy ogólnych, comiesięcznych konferencji, zapraszał rekolekcjonistę z kazaniami, brał udział w konferencjach ogólnopolskich. Od władzy diecezjalnej otrzymywał wytyczne i przed nią składał roczne sprawozdania.

Diecezja łomżyńska, podobnie jak drohiczyńska, nieposiadające w latach pięćdziesiątych wyższych uczelni na swoim terenie, proszone były przez bp. Golińskiego o świadczenie na rzecz białostockiego ośrodka Duszpasterstwa Akademickiego. Białystok bowiem do tej pory korzystał wyłącznie z ofiar wiernych i jednej niedzielnej tacy w miesiącu z parafii farnej.

Rozwój Duszpasterstwa Akademickiego, szczególnie ożywione kontakty księży duszpasterzy z młodzieżą akademicką, rodził nowe wyzwania. Zaistniała pilna potrzeba stworzenia przy ośrodku duszpasterskim czytelni katolickiej z zasobem książek o tematyce filozoficznej i teologicznej, jak i umieszczenia tablic informacyjnych Duszpasterstwa Akademickiego przy wszystkich świątyniach miasta. Proboszczowie parafii zostali zobowiązani do odsyłania do duszpasterzy akademickich interesantów, jeśli byli związani z uczelniami wyższymi.

Temat ogólny roku pracy duszpasterskiej 1955/1956 w ramach Duszpasterstwa Akademickiego brzmiał: „Osobowość inteligentnego katolika-Polaka”. Comiesięcznymi tematami spotkań były:

1. Rola światopoglądu katolickiego w kształtowaniu osobowości Polaka.

2. Światopogląd katolicki w spotkaniu ze światopoglądem naukowym.

3. Jestem osobą przez duszę i ciało.

4. Jestem osobą, ale osobowość moja podlega kształtowaniu.

5. Istnieje Bóg osobowy.

6. Odwieczna osoba Syna Bożego zaistniała również w ludzkiej naturze.

7. Najwznioślejszą funkcją osobową człowieka jest życie religijne zjednoczone z Chrystusem.

8. Wartość czynu człowieka w zastawieniu z intencją wsławiania Boga.

9. Celem życia ludzkiego jest wsławianie Boga w czynie świadomym, a nie tylko rzeczowym.

10. Społeczna funkcja Kościoła Chrystusowego.

11. Maryja Matka Mistycznego Ciała Chrystusa.

Roczne rekolekcje akademickie odbywały się na temat: Drogi prowadzące do ukształtowania osobowości chrześcijanina ${ }^{11}$.

11 AAB, TDA, Sprawy organizacyjne Duszpasterskiego Ośrodka, Sprawozdanie z konferencji Kolegium Duszpasterstwa Akademickiego, z 7.X.1955 r. 
14 października 1955 roku w gmachu Kurii, z inicjatywy ks. Adama Sawickiego, odbyła się Konferencja Plenarna Duszpasterstwa Akademickiego z udziałem duszpasterzy akademickich. Udział w niej wzięli, poza wikariuszem kapitulnym, także ks. Adam Abramowicz - proboszcz parafii św. Rocha, ks. Stanisław Urban - proboszcz parafii Wniebowzięcia Najświętszej Maryi Panny, ks. Witold Pietkun, ks. Piotr Boryk, ks. Jan Zabański, ks. Zenon Łasowski, ks. Maciej Pawlik i ks. Edward Kisiel. Przedstawiony został na nim kanon prawa kanonicznego o szkołach wyższych (kan. 1373 CIC) oraz jego interpretacja w świetle wytycznych statutowych Duszpasterstwa Akademickiego w Polsce. Ksiądz Pietkun przedstawił początki Duszpasterstwa Akademickiego w Białymstoku (od marca 1954) i zdał krótkie sprawozdanie z działalności Duszpasterstwa. Wikariusz kapitulny, A. Sawicki, przedstawił tekst instrukcji przygotowanej do duszpasterzy terenowych.

Z polecenia ks. Sawickiego odbyły się wybory przewodniczącego Kolegium Duszpasterzy Akademickich, sekretarza i skarbnika. W porozumieniu z proboszczami ustalono duszpasterzy terenowych przy kościołach białostockich. Przewodniczącym Kolegium został ks. Pietkun, sekretarzem ks. Kisiel, skarbnikiem ks. Boryk. Czas kadencji ustalono na jeden rok. Duszpasterzem parafialnym przy kościele farnym był ks. Boryk, przy kościele św. Wojciecha ks. Zabański, przy kaplicy seminaryjnej ks. Pawlik, a przy kościele św. Rocha ks. Zygmunt Lewicki, gdyż ks. Adam Sawicki, wikariusz kapitulny, zasugerował, by do pierwotnego grona duszpasterzy dołączyć jeszcze ks. Lewickiego.

Podjęto decyzję, by przy kościele farnym i św. Rocha założyć ośrodki samokształcenia religijnego, ustalić dni i godziny przyjęć duszpasterstwa parafialnego przy każdym kościele. Sprawę stworzenia funduszu akademickiego diecezjalnego i międzydiecezjalnego planowano omówić w gronie Kolegium w porozumieniu z Kurią Arcybiskupią ${ }^{12}$.

Zajęto się też najpilniejszymi sprawami: kwestią tworzenia ośrodków samokształcenia religijnego, wizytacjami duszpasterskimi, czy organizacją Dnia Studenta ${ }^{13}$.

Ksiądz Pietkun, który położył podwaliny pod organizację Duszpasterstwa Akademickiego w Białymstoku, choć był przewodniczącym Kolegium Duszpasterzy Akademickich, to jednak miał brać udział w pracach Kolegium jako primus inter pares. Wszystkie sprawy załatwiane były zwykłą większością głosów, a bardziej ważne wymagały akceptacji władzy diecezjalnej. Wikariusz kapitulny oczekiwał od księży: P. Boryka, E. Kisiela, J. Zabańskiego, M. Pawlika, J. Trochima i Z. Lewickiego złożenia projektu „Regulaminu Duszpasterstwa Akademickiego w Białymstoku"14.

12 AAB, TDA, Konferencja w sprawie organizacji pracy Duszpasterstwa Akademickiego w Białymstoku, Białystok 14.X.1955 r., mps.

13 AAB, TDA, Porządek konferencji Duszpasterstwa Akademickiego pod przewodnictwem wikariusza kapitulnego ks. prałata Adama Sawickiego, 14.X.1955 r.

14 AAB, TDA, Odręczna notatka ks. A. Sawickiego. 
27 listopada 1955 roku Kuria Biskupia w Białymstoku wydała list skierowany do proboszczów i rektorów kościołów mówiący o potrzebie objęcia troską duszpasterską środowiska akademickiego w Białymstoku.

W Białymstoku, oprócz Seminarium Duchownego przeniesionego z Wilna do Białegostoku w 1945 roku i mającego tradycje uniwersyteckie przez związki z Wydziałem Teologicznym Uniwersytetu Stefana Batorego w Wilnie, od 1950 roku istniała Akademia Medyczna oraz Wieczorowa Szkoła Inżynieryjna i Studium Nauczycielskie. Ogółem w roku 1955 studiowało w Białymstoku około 1600 studentów, a na trzech uczelniach wyższych pracowało prawie 400 pracowników naukowych. Społeczność akademicka składała się w większości z katolików. W myśl prawa kanonicznego (kan. 1373 §2 CIC) studenci mieli zostać objęci opieką duszpasterską. Przy każdym kościele na terenie miasta zostali powołani kapłani, którzy pełnili funkcję duszpasterzy akademickich. Już w pierwszych miesiącach swej posługi sygnalizowali o szerokich potrzebach, nie tylko duszpasterskich, ale i materialnych. Wielu studentów borykało się z problemami materialnym, byli zagrożeni gruźlicą i anemią, żyli w trudnych warunkach mieszkaniowych.

Kuria Biskupia w Białymstoku prosiła proboszczów i rektorów kościołów, by podzielili się tymi wiadomościami z wiernymi, uwrażliwili ich na potrzeby środowiska akademickiego i zachęcili do ofiar na rzecz Duszpasterstwa Akademickiego. W czasie ferii i wakacji zostali zobowiązani do otoczenia opieką duchową i materialną parafialną młodzież szkół wyższych urządzając wspólną adorację Najświętszego Sakramentu, przeprowadzając konferencje religioznawcze lub w inny sposób oddziałując wychowawczo. Kuria liczyła także na zgromadzenie uwag dotyczących przyszłej posługi duszpasterskiej ${ }^{15}$.

Dnia 19 grudnia 1955 roku ks. Pietkun przedstawił projekt „Regulaminu Duszpasterstwa Akademickiego w Białymstoku"16. Uczynił to na wyraźną prośbę ks. Adama Sawickiego, wikariusza kapitulnego.

4 listopada 1956 roku podczas comiesięcznego nabożeństwa odbyła się konferencja do społeczności akademickiej, którą wygłosił ks. Pietkun. Tematem była sytuacja Kościoła w Polsce w okresie kultu jednostki.

Kilka dni później w starym kościele farnym, zamiast przewidzianego wykładu Wyższej Wiedzy Religijnej odbyło się dyskusyjne konwersatorium religioznawcze nt. „Czy Kościół katolicki może być uważany za państwo w państwie?”17.

23 listopada 1956 roku odbyła się konferencja Kolegium Duszpasterzy Akademickich w Białymstoku, podczas której ks. Pietkun złożył sprawozdanie z pracy duszpasterskiej w Duszpasterstwie Akademickim.

Przeobrażenia w kraju w 1956 roku połączone były z silnym akcentem postawy katolickiej społeczeństwa, także młodzieży akademickiej. Żądano

15 AAB, TDA, Pismo Kurii Biskupiej w Białymstoku do księży proboszczów i rektorów, z 27.XI.1955 r.

16 AAB, TDA, Regulamin Duszpasterstwa Akademickiego w Białymstoku (projekt) ułożony na polecenie przewielebnego ks. prałata Adama Sawickiego wikariusza kapitulnego, 19.XII.1955 r.

17 AAB, TDA, Notatka ks. E. Kisiela, z 26.X.1956 r. 
uwolnienia z miejsca internowania Prymasa Polski, kard. Stefana Wyszyńskiego, powrotu religii do szkół, przywrócenia praw kapłanom dotychczas poddanym represjom administracyjno-karnym. Szczególnym tego wyrazem był protest w Białymstoku, który przerodził się w manifestację wolnościową zakończoną Mszą św. w kościele pw. św. Rocha i Królowej Polski. Uczestniczyli w niej nie tylko robotnicy, ale przede wszystkim młodzież, gdzie młodzież akademicka odgrywała rolę wiodącą.

W prokatedrze białostockiej, podczas inauguracji roku akademickiego 1956/1957, odbyło się ślubowanie akademickiej młodzieży, hołd złożony przez nią Królowej Polski. Ksiądz Pietkun sugerował, by stworzyć wszystkiej młodzieży skupionej wokół Duszpasterstwa Akademickiego możliwość złożenia pod tym aktem swego podpisu. Młodzież, która w 1956 roku wzięła udział w pielgrzymce akademickiej na Jasną Górę stanowiła zalążek katolickiego aktywu. Były to 53 osoby z białostockiego ośrodka Duszpasterstwa Akademickiego. Ksiądz Pietkun sugerował, by ks. Henryk Gulbinowicz przynajmniej raz w miesiącu odbywał z nimi spotkania duszpasterskie. Prócz ks. Gulbinowicza udział w pielgrzymce i w jej zorganizowaniu wzięli także ks. M. Pawlik oraz ks. Z. Lewicki.

Inauguracji roku akademickiego w białostockiej farze przewodniczył wikariusz kapitulny ks. Adam Sawicki. To on przyjął ślubowanie młodzieży akademickiej. Było trochę uzasadnionego żalu wobec parafii, gdyż liczono na udział w nabożeństwie parafialnego chóru. Jego brak spowodował, że postanowiono stworzyć akademicki chór lub przynajmniej scholę akademicką. Zgodnie ze „Statutem Duszpasterstwa Akademickiego w Polsce” na gruncie terenowym Duszpasterstwo Akademickie występowało jako równorzędny partner wobec proboszczów, czy rektorów kościołów. Niejednokrotne trudności, jakie się rodziły na linii proboszcz - duszpasterz akademicki powodowały, że ks. Pietkun zasugerował potrzebę wydzielenia starego, „białego”, kościoła farnego spod jurysdykcji proboszcza i poddania go wyłącznej kompetencji rezydującego tam duszpasterza akademickiego do czasu wybudowania w Białymstoku odrębnej świątyni akademickiej. Zdarzały się bowiem takie sytuacje, że ks. Stanisław Urban, proboszcz parafii Wniebowzięcia Najświętszej Maryi Panny, ingerował w temat comiesięcznej konferencji akademickiej lub kwestionował konieczność prowadzenia dyskusji religioznawczych w Starym Kościele, choć w nim odbywały się lekcje katechezy i wykłady Studium Wyższej Wiedzy Religijnej.

Inną niecierpiącą zwłoki sprawą było wydzielenie w Białymstoku przynajmniej jednego kapłana do wyłącznej pracy w Duszpasterstwie Akademickim. Dotychczas wszyscy kapłani byli bowiem zaangażowani równocześnie w duszpasterstwo parafialne, a nawet w pełnowymiarową katechezę szkolną. Według pierwotnego planu miał być nim ks. Henryk Gulbinowicz, ale został obarczony w parafii wieloma godzinami katechezy. Ksiądz Pietkun apelował do rządcy diecezji o uregulowanie tej kwestii personalnej. 
Ksiądz Witold Pietkun uważał, iż jego dalsze angażowanie się w działalność Duszpasterstwa Akademickiego jest niemożliwe z wielu względów. Był przekonany, że kierowanie i wzięcie odpowiedzialności za tak ważny odcinek duszpasterstwa wiąże się z posiadaną władzą, a nie tylko przywilejem zdanym na łaskę innych członków Kolegium. Uważał, że kierujący pracami Duszpasterstwa Akademickiego może występować tylko i wyłącznie z ramienia Referatu Duszpasterskiego Kurii Arcybiskupiej, a nie być zdanym na wybory i decyzje innych kapłanów-duszpasterzy. Nie chciał brać udziału w publicznych wystąpieniach jako duszpasterz akademicki, gdyż w lutym 1956 roku został pozbawiony przez rektora Archidiecezjalnego Wyższego Seminarium Duchownego w Białymstoku praw wykładowcy, co uważał za odpowiedź lokalnych władz kościelnych na żądania władz państwowych, by ukrócić jego działalność duszpasterską i patriotyczną. Zbyt wiele wysiłku kosztowało go rozpoczęcie działalności w Duszpasterstwie Akademickim, przy jednoczesnym bojkotowaniu jego osoby przez środowiska kościelne. Bał się także o swoją wolność osobistą, a nawet życie. Ciągle był inwigilowany i śledzony przez funkcjonariuszy państwowych; wszystkie jego publiczne wystąpienia były kontrolowane i poddawane osądowi. Toczyły się przeciwko niemu sprawy sądowe i administracyjne, dlatego uważał, że nie powinien obejmować funkcji kierowniczej w Duszpasterstwie Akademickim. Sugerował, by tego dzieła podjął się kapłan, który nie był w żaden sposób dyskryminowany i szykanowany przez władze ${ }^{18}$.

W grudniu 1956 roku ks. Adam Sawicki skierował na ręce ks. Pietkuna pismo, w którym wyraźnie stwierdzał, iż istniejące wówczas w Białymstoku kościoły nie wystarczały do obsługi wiernych katolików w duszpasterskiej posłudze parafialnej. Odpowiadał, że na wydzielenie osobnego kościoła jako ośrodka pełnej pracy religijnej i duszpasterskiej dla społeczności akademickiej w Białymstoku nie ma szans i nie ma co o tym marzyć. Kuria Arcybiskupia poleciła duszpasterzom akademickim, by zastanowili się nad tą sprawą obmyślając miejsca i obiekty konieczne i pożyteczne do realizacji tegoż celu. Wyniki tych przemyśleń miał Kurii przedstawić ks. Pietkun ${ }^{19}$.

W czerwcu 1957 roku ks. W. Pietkun wraz z ks. Kisielem wysłali na adres Sekretariatu Duszpasterstwa Akademickiego w Warszawie pismo z sugestią, by podział funduszów przekazywanych na potrzeby poszczególnych ośrodków Duszpasterstwa Akademickiego w Polsce odbywał się nie według ilości studentów na uczelniach, ale według faktycznej ich łączności z ośrodkiem duszpasterskich. Białystok tracił bowiem finansowo na takim podziale środków. Nie mógł się równać z wielkimi miastami i dużymi ośrodkami akademickimi, takimi jak choćby Warszawa, Poznań, Kraków, czy Lublin ${ }^{20}$.

18 AAB, TDA, Sprawozdanie ks. W. Pietkuna o sytuacji na bieżący rok pracy w Duszpasterstwie Akademickim, Białystok 23.XI.1956 r.

19 AAB, TDA, Pismo wikariusza kapitulnego do ks. W. Pietkuna, z dn. 18.XII.1956 r.

20 AAB, TDA, Pismo ks. W. Pietkuna i ks. E. Kisiela do Sekretariatu Duszpasterstwa Akademickiego w Warszawie, z 28.VI.1957 r. 
Rok akademicki 1956/1957 był owocny dla Duszpasterstwa Akademickiego, gdyż z miejsca odosobnienia wrócił Prymas Polski kard. Stefan Wyszyński. Ustały też kroki prawne skierowane przeciwko ks. Pietkunowi. Władza diecezjalna mianowała ks. dr Henryka Gulbinowicza wikariuszem w białostockiej farze, jednocześnie skierowując go do pracy z młodzieżą akademicką. Mieszkanie ordynariusza zostało zaadaptowane na tymczasowy sekretariat Duszpasterstwa Akademickiego.

Zimą 1956 roku udało się duszpasterzom akademickim zorganizować opłatek akademicki w Starym Kościele farnym, imprezę andrzejkową w parafii św. Rocha; na zaproszenie młodzieży księża złożyli wizytę duszpasterską w białostockich akademikach. Złożyli także oficjalną wizytę u trzech rektorów białostockich uczelni. Wczesną wiosną 1957 roku odbyły się cztery serie rekolekcji wielkopostnych i dwie pielgrzymki na Jasną Górę. Imponująco wypadła uroczystość złożenia Ślubów Jasnogórskich przez młodzież akademicką w kościele pw. św. Rocha i Najświętszej Maryi Panny Królowej Polski na początku maja 1957 roku. Odbyło się wiele spotkań z duszpasterzami i różnorodne nabożeństwa.

Latem 1957 roku ks. Gulbinowicz został przeniesiony z fary do parafii św. Rocha $^{21}$. Fakt ten pozbawił najliczniejsze środowisko akademickie zaangażowanego duszpasterza akademickiego. Ksiądz Gulbinowicz utracił tym samym kontakt ze środowiskiem akademickim. Translokacja była o tyle niefortunna, że dokonano jej w momencie planowania pracy duszpasterskiej na kolejny rok akademicki. Mimo protestu ks. Pietkuna przenosiny stały się faktem.

Ksiądz Pietkun wystosował na ręce wikariusza kapitulnego pismo, w którym przedstawił własne uwagi. Proponował Duszpasterstwo Akademickie kreować ponownie, a stary kościół farny przekazać pod wyłączną kompetencję kierownika Duszpasterstwa Akademickiego, którego trzeba było mianować na piśmie także kierownikiem sekretariatu Duszpasterstwa Akademickiego. Kościółek farny miał być też dostępny dla innych grup działających w parafii. Msza św. w farze o godz. $12.45 \mathrm{w}$ dni świąteczne miała zostać wyjęta spod kompetencji parafialnej, a poddana Duszpasterstwu Akademickiemu. Taca z tej Mszy św. miała stanowić zaplecze finansowe na funkcjonowanie sekretariatu i całego Duszpasterstwa Akademickiego. Proponował wyznaczenie w parafii farnej duszpasterza terenowego mającego do swej dyspozycji pokój na przyjmowanie studentów w godzinach ogólnie wiadomych.

Sekretariat ogólnomiejski Duszpasterstwa Akademickiego mógł się znajdować w parafii św. Rocha. Ksiądz Pietkun proponował, by kierownikiem Duszpasterstwa Akademickiego w mieście został ks. Gulbinowicz. Miał on dobrać sobie do pomocy, z grona duszpasterzy terenowych, księdza-sekretarza. Eucharystia o godz. 12.30 miała być Mszą św. akademicką. Duszpasterz terenowy w parafii św. Rocha miał korzystać z sekretariatu Duszpasterstwa lub z pomieszczeń parafialnych.

${ }_{21}$ L. Wołosiuk, A kościół trwa. Rozmowy z Kardynałem Gulbinowiczem, Wrocław 2000, s. 119-124. 
Dopiero po spełnieniu tychże warunków ks. Pietkun mógł wyrazić zgodę na dalszą współpracę z sekretariatem i Kolegium Duszpasterzy Akademickich w formie zamianowanego referenta kurialnego do spraw Duszpasterstwa Akademickiego. Ksiądz Pietkun uważał, iż kościół św. Wojciech miał bardzo dobre położenie i nadawał się wyśmienicie na kościół akademicki. Ale musiał tam być duszpasterz akademicki, który byłby jednocześnie rektorem tejże świątyni. Dopiero wówczas można było myśleć o przeniesieniu Duszpasterstwa Akademickiego z fary do kościoła św. Wojciecha, przy ul. Warszawskiej.

Od września 1957 roku 0,5 grosza „od duszy” ze wszystkich parafii miało być formą materialnego wsparcia dla Duszpasterstwa Akademickiego ${ }^{22}$.

Mimo kilkakrotnych propozycji ze strony wikariusza kapitulnego ks. Pietkun nie wziął udziału w ogólnopolskiej konferencji duszpasterzy akademickich w Warszawie 26 września 1957 roku. Oczekiwał jednoznacznej odpowiedzi i reakcji ze strony ks. Sawickiego na pismo z 10 września 1957 roku. W jego miejsce do Warszawy pojechał ks. Gulbinowicz. Po powrocie przedstawił on wikariuszowi kapitulnemu wskazania ogólnopolskiej konferencji ${ }^{23}$.

12 października 1957 roku odbyła się inauguracja kolejnego roku pracy Duszpasterstwa Akademickiego w Białymstoku. Przy okazji ks. Pietkun zwrócił się do wikariusza kapitulnego ks. Sawickiego z prośbą, by przygotować i wydać dekret dotyczący Duszpasterstwa Akademickiego w Białymstoku. Miał on uwzględniać dotychczasowe doświadczenia terenowe (jak i kanon 1373 CIC) i uchwałę plenarną Konferencji Episkopatu Polski. Ksiądz Pietkun sugerował, iż przy zredagowaniu dekretu pomóc mógłby ks. Czesław Kulikowski ${ }^{24}$, jako kanonista. Prosił go już zresztą o napisanie komentarza po ukazaniu się dekretu. Dekret miałby ukazać się w specjalnym numerze „Akademickich Wiadomości Kościelnych". Sekretariat ogólnopolski Duszpasterstwa Akademickiego miał przystąpić do opracowywania statutu ogólnopolskiego Duszpasterstwa Akademickiego na podstawie doświadczeń diecezjalnych.

Mszy św. inaugurującej nowy rok akademicki przewodniczył bp Władysław Suszyński. Nad całością czuwał nowo mianowany duszpasterz akademicki ks. Henryk Gulbinowicz. Cztery lata istnienia Duszpasterstwa Akademickiego w Białymstoku zaowocowały tym, że w mieście nad rzeką Białą Duszpasterstwo Akademickie istniało jako samodzielna instytucja, jako jednostka personalnego duszpasterstwa obok dwu parafii terenowych - Wniebowzięcia Najświętszej Maryi Panny i św. Rocha ${ }^{25}$.

${ }^{22} \quad$ AAB, TDA, Pismo ks. W. Pietkuna w sprawie sytuacji Duszpasterstwa Akademickiego do ks. prałata Wikariusza kapitulnego w Białymstoku, z 10.IX.1957 r.

23 AAB, TDA, Wskazania Ogólnopolskiej Konferencji Duszpasterzy Akademickich, Warszawa 26.IX.1957, z 28.IX.1957 r.

24 T. Krahel, Przez Kozielsk i Monte Cassino - ks. Czesław Kulikowski, „W Służbie Miłosierdzia” 2005, nr 3, s. 17.

25 AAB, TDA, Pismo ks. W. Pietkuna, Sprawozdanie z inauguracji roku akademickiego 1957/1958 do wikariusza kapitulnego ks. A. Sawickiego, z 13.X.1957 r. 
Przed rozpoczęciem roku akademickiego 1957/1958 ks. Sawicki spisał notatkę, dzięki której wiemy, czym się kierował przy translokatach księży. Terenowi duszpasterze akademiccy zostali zamianowani zbiorowo, a ks. H. Gulbinowicz nie będąc wikariuszem w parafii otrzymał oddzielną nominację na kierownika sekretariatu Duszpasterstwa Akademickiego. Do jego kompetencji należało: troszczyć się nad całością pracy duszpasterskiej w społeczności akademickiej, szczególnie w sferze religijnej, kulturalnej i charytatywnej. Wytyczne ogólne otrzymywał od referatu Duszpasterstwa Akademickiego w Kurii Arcybiskupiej. Warunki pracy omawiane były na konferencjach Kolegium Duszpasterzy Akademickich. Pracami Kolegium kierował przewodniczący wybierany na zebraniu plenarnym i potwierdzany przez Kurię. Referent kurialny Duszpasterstwa Akademickiego sprawował funkcję kontrolującą, doradczą i koordynującą pracę białostockiego środowiska z ogólnopolskim sekretariatem Duszpasterstwa Akademickiego.

Ksiądz Cz. Kulikowski miał być powołany na przewodniczącego komitetu budowy ośrodka akademickiego, gdyż miał kontakty w Stanach Zjednoczonych. Na materialną pomoc z USA liczono przy ewentualnej budowie kościoła akademickiego ${ }^{26}$.

12 października 1957 roku do Kolegium Duszpasterzy Akademickich zostali powołani przez ks. prałata A. Sawickiego następujący księża: E. Kisiel, J. Zabański, S. Piotrowski, M. Pawlik, Z. Lewicki, H. Gulbinowicz. Obowiązki głównego duszpasterza akademickiego powierzono ks. Gulbinowiczowi. Wikariusz kapitulny Archidiecezji w Białymstoku, ks. Adam Sawicki, mianował ks. Pietkuna seniorem, czyli przewodniczącym Kolegium Duszpasterzy Akademickich. Uczynił to w dowód uznania za wkład w organizowanie Duszpasterstwa Akademickiego wśród społeczności akademickiej miasta. Miał bowiem doświadczenie w pracy z młodzieżą studencką, cieszył się ogromnym autorytetem ${ }^{27}$.

Jesienią 1957 roku trwały starania w celu zgromadzenia środków materialnych na budowę przyszłej świątyni akademickiej w Białymstoku. Ksiądz Pietkun miał nadzieję na pozytywną odpowiedź Polonii Amerykańskiej, choć bał się też, aby „rodacy nie poprzestali na rzucaniu kwiatami, jak ongiś na płonącą w powstaniu Warszawę $e^{\prime 28}$.

W grudniu 1956 roku wikariusz kapitulny zlecił oszacowanie możliwości budowy kościelnego ośrodka Duszpasterstwa Akademickiego w Białymstoku. 20 grudnia 1956 roku Kolegium Duszpasterzy Akademickich w Białymstoku wysłało pismo do Rady Polonii w USA z prośbą o konkretną pomoc. W maju 1957 roku prośbę tę ponowiono wobec Polek z Amerykańskiej Polonii, które przybyły z pielgrzymką na Jasną Górę. Ale ponieważ wszelkie petycje z Polski nie były

AAB, TDA, Notatka ks. A. Sawickiego do sformułowania przydziałów.

27 AAB, TDA, Nominacja ks. W. Pietkuna na seniora Duszpasterstwa Akademickiego w Białymstoku, z dn. 12.X.1957 r.

28 AAB, TDA, Pismo ks. W. Pietkuna, Sprawozdanie z inauguracji roku akademickiego 1957/1958 do wikariusza kapitulnego ks. A. Sawickiego, z 13.X.1957 r. 
rozpatrywane w USA bez wyraźnej aprobaty Prymasa kard. Stefana Wyszyńskiego zwrócono się do niego z prośbą o pomoc. Katolickie organizacje w Ameryce otrzymały bowiem od władz kościelnych w Polsce zastrzeżenie, by pomoc dla kraju odbywała się za pośrednictwem, a przynajmniej wiedzą, Prymasa Polski. Kierownictwo Duszpasterstwa Akademickiego w Białymstoku prosiło ordynariusza o zreferowanie sprawy Prymasowi, ale o wynikach rozmów nic nie było wiadomo. Ksiądz Kulikowski, znając nieco Polonię Amerykańską, widział możliwości zrealizowania pomysłu budowy kościoła akademickiego dzięki jej materialnemu wsparciu. Liczono na to, iż świątynia Duszpasterstwa Akademickiego stanie się nie tylko miejscem kultu, ale i ośrodkiem polskiej kultury, w mieście, gdzie polskość była mocno podważana przez środowiska białoruskie. Kwestia budowy kościoła dla Duszpasterstwa Akademickiego została też omówiona z biskupami Zdzisławem Golińskim i Tomaszem Wilczyńskiem, i znalazła ich aprobatę ${ }^{29}$.

24 listopada 1957 roku ks. Czesław Kulikowski napisał list do Prymasa Polski z prośbą o pomoc w budowie kościoła akademickiego w Białymstoku. Szukał poparcia idei budowy nowej świątyni i pomoc w przeprowadzeniu kwesty wśród Polaków w Stanach Zjednoczonych ${ }^{30}$.

Odpowiedź Prymasa Polski z grudnia 1957 roku nie pozostawiała złudzeń, iż nie uda się pozyskać środków od Polonii Amerykańskiej. Prymas uważał, że wówczas nie było możliwości, by w USA zabiegać o pomoc w budowie akademickiej świątyni, zanim inne potrzeby, na które uwrażliwiona była opinia publiczna, nie były należycie określone i zaspokojone ${ }^{31}$. Prymas polecił czekać na powrót z USA bp. Karola Pękali.

11 lutego 1958 roku ks. Władysław Padacz, osobisty sekretarz Prymasa Polski, poinformował ks. Pietkuna, że sprawa budowy kościoła akademickiego w Białymstoku należy wyłącznie do kompetencji Kurii Białostockiej32.

W ciągu roku akademickiego 1957/1958 Msze św. w niedziele i święta odprawiane były dla społeczności akademickiej o godz. $9.00 \mathrm{w}$ starym kościele farnym (z frekwencją ok. 300 osób) i o 12.45 w nowym kościele farnym. W dni powszechnie społeczność akademicka korzystała z nabożeństw odprawianych według porządku parafialnego.

Duszpasterz główny odwiedzał chorych studentów, przebywającym w szpitalach dostarczał literatury katolickiej, udzielał sakramentów św., a w Klinice Chorób Płucnych, za zgodą przełożonych Kliniki, przeprowadził nawet dwie serie rekolekcji wielkopostnych.

29 AAB, TDA, Załącznik do listu ks. Cz. Kulikowskiego do Prymasa Polski, Sprawa budowy ośrodka Duszpasterstwa Akademickiego w Białymstoku, z 24.XI.1957 r.

30 AAB, TDA, Pismo ks. Cz. Kulikowskiego do Prymasa Polski, z 24.XI.1957 r.

31 AAB, TDA, Pismo Prymasa Polski kard. Stefana Wyszyńskiego do ks. Cz. Kulikowskiego, z 9.XII.1957 r.

32 AAB, TDA, Pismo ks. W. Pietkuna do ks. prał. A. Sawickiego wikariusza kapitulnego w sprawie budowy ośrodka akademickiego, z 11.II.1958 r. 
Czynne były dwa sekretariaty Duszpasterstwa Akademickiego, przy farze (w godz. 10.30-12.30) i przy św. Rochu (w godz. 15.00-18.00) we wszystkie dni tygodnia. Miejsca spotkań odwiedzało około 15 osób dziennie. W niedziele i święta w godzinach wieczornych sekretariaty te wykorzystywano na wieczory dyskusyjne, wykłady i konwersatoria. Każdy z księży należących do Kolegium Duszpasterzy Akademickich przyjmował studentów w określonym czasie.

W miesiącach: grudniu, lutym, maju i czerwcu odbyły się miesięczne dni skupienia. W Adwencie odprawiane były w każdą niedzielę roraty w starym kościele. W Wielkim Poście odbyły się rekolekcje akademickie w dwóch turach: w kościele farnym w dniach 2-6 marca 1958 roku (o. Tomasz Rostworowski SJ, duszpasterz akademicki z Lublina), 12-16 marca 1958 roku w starym kościele (ks. W. Pietkun). Przez cztery niedziele Wielkiego Postu w kościele św. Rocha rekolekcje głosił ks. Cz. Kulikowski.

W okresie kolędowym księża odwiedzili młodzież akademicką mieszkającą w domach akademickich i na mieście.

18 maja 1958 roku grupa około 70 studentów, wraz z ks. Piotrowskim i Pawlikiem, wzięła udział w akademickiej pielgrzymce na Jasną Górę. Pozostała młodzież akademicka tegoż dnia odnowiła śluby maryjne na Mszy św. o godz. 18.00 w kościele św. Rocha.

27 maja 1958 urządzono Mszę św. absolwencką. Wzięło w niej udział blisko 90\% absolwentów Akademii Medycznej. Po Mszy św. na terenie wokół kościoła nastąpiło spotkanie biskupa z młodymi medykami.

23 czerwca 1958 roku po raz pierwszy zorganizowano Mszę św. dla absolwentów Studium Nauczycielskiego.

W lokalu Duszpasterstwa Akademickiego odbywały się 2-3 razy w tygodniu konwersatoria z zagadnienia Pisma Świętego, teologii i etyki, a także dyskusje nad aktualnymi zagadnieniami. Odbyły się cztery wieczory poświęcone zapoznaniu młodzieży akademickiej z katolicką literaturą piękną, z udziałem ks. prof. Stanisława Marcinkowskiego. W sekretariacie Duszpasterstwa Akademickiego czynna była biblioteczka, z której w ciągu roku wypożyczono 729 tomów. Dla grupy młodzieży akademickiej repatriacyjnej od listopada 1957 roku do kwietnia 1958 roku odbywały się wykłady z języka polskiego i historii literatury prowadzone w każdą niedzielę przez ks. Marcinkowskiego.

W roku 1957/1958 odbywały się też imprezy kulturalno-oświatowe i rekreacyjne. W październiku 1957 roku studenci udali się do Supraśla, a w listopadzie 1957 roku na groby pomordowanych w czasie II wojny światowej w Grabówce w celu uczczenia pamięci męczenników za wiarę i Ojczyznę. Była to też jedna z form wychowania patriotycznego. Wieczór andrzejkowy cieszył się ogromnym powodzeniem. W grudniu odbył się opłatek z udziałem bp. W. Suszyńskiego. W karnawale był kulig 70-osobowy. W maju 1958 roku zorganizowano podmiejską wycieczkę z odwiedzeniem grobów na Pietraszach. 
W roku akademickim 1957/1958 powstał Akademicki Chór Kościelny liczący 25 osób. Próby odbywały się co tydzień. Chór towarzyszył Mszy św. o godz. 9.00, na rekolekcjach, na Mszy św. absolwenckiej.

Podczas wakacji letnich 1958 roku młodzież akademicka urządziła obóz letni (14-31 lipca 1958) na 45 osób. Wiele z form obozowego życia zostało zauważonych nawet przez delegata Episkopatu bp. Tomasza Wilczyńskiego, który na ogólnopolskim posiedzeniu Duszpasterstwa Akademickiego w Otwocku (23 września 1958) uznał letni wypoczynek białostockich studentów za wzorcowy i godny naśladowania ${ }^{33}$.

10 października 1958 roku wikariusz kapitulny ks. Adam Sawicki wydał specjalne „Wytyczne pracy Duszpasterstwa Akademickiego w Białymstoku na rok 1958/1959"34. W 16 punktach podął podstawowe i najważniejsze cele i zadania Duszpasterstwa Akademickiego w Białymstoku. Miało ono stanowić skoordynowaną opiekę duszpasterską księży, powołanych przez władzę diecezjalną, nad środowiskiem szkół wyższych w Białymstoku.

Ośrodkiem akademickiej pracy duszpasterskiej dla całego miasta był stary kościół farny, „biały kościółek”. Inne świątynie miasta, takie jak: fara, kościół św. Wojciecha oraz kaplica Seminarium Duchownego były pomocniczymi ośrodkami. Każda w tych świątyń na miarę swych możliwości i potrzeb służyła Duszpasterstwu Akademickiemu. Stworzenie odpowiednich warunków lokalowych i zaplecza materialnego spoczywało głównie na administratorach tych obiektów. Przy każdej z wymienionych świątyń był kapłan odpowiedzialny za duszpasterstwo akademickie, który przyjmował studentów w wyznaczonych godzinach.

Pracą Duszpasterstwa Akademickiego kierowało Kolegium Duszpasterzy Akademickich, które ze swego grona wybierało głównego duszpasterza akademickiego oraz sekretarza. Członkowie Kolegium planowali pracę duszpasterską na kolejne lata; ustalali porządek nabożeństw stałych, okresowych i termin rekolekcji akademickich oraz innych nabożeństw i zebrań. Grono duszpasterzy koordynowało także działalność charytatywną i religijno-kulturalną. W gronie Kolegium było także stanowisko honorowe, tzw. seniora (był nim ks. Witold Pietkun), do którego Kolegium nie było zobowiązane zwracać się o rady. Senior nie miał też prawa do bezpośredniej interwencji w sprawach Duszpasterstwa, mógł jednak służyć pomocą i sugerować wszelkie poczynania. Zebrania Kolegium odbywały się na wniosek głównego duszpasterza lub kilku jego członków kilka razy w roku. Podczas obrad Kolegium przewodniczyli jego członkowie.

Przed rozpoczęciem każdego roku akademickiego odbywało się spotkanie Kolegium, w którym brał udział ordynariusz diecezji. Ocenie poddawano

33 AAB, TDA, Sprawozdanie ks. Pietkuna przesłane do ks. prałata A. Sawickiego wikariusza kapitulnego z działalności Duszpasterstwa Akademickiego w Białymstoku za rok akademicki 1957/1958, z 30.IX.1958 r.

34 AAB, TDA, Wytyczne pracy Duszpasterstwa Akademickiego w Białymstoku na rok akademicki 1958/1959, z 10.X.1958 r. 
miniony rok pracy duszpasterskiej, dyskutowano i przyjmowano projekty i główne wytyczne na rok następny oraz zastanawiano się nad kwestiami personalnymi.

Do zadań głównego duszpasterza akademickiego miasta Białegostoku należało: przewodniczenie nabożeństwom w kościele, podejmowanie studentów w siedzibie Duszpasterstwa Akademickiego, prowadzenie księgi kasowej, przedstawianie sprawozdań finansowych z poczynionych stosownie do wskazań Kolegium wydatków, administracja majątkiem Kolegium oraz podtrzymywanie kontaktów z seniorem oraz władzą diecezjalną. W pracy duszpasterskiej wspierał go każdy z członków Kolegium. W wypadku, gdyby któryś student zwrócił się z prośbą o posługę duszpasterską w parafiach to duszpasterz brał na siebie pomoc w porozumieniu z miejscowym proboszczem. On sam lub któryś z członków Kolegium uczestniczył w ogólnopolskich konferencjach i zjazdach duszpasterzy akademickich. Opracowywał też konferencje i sprawozdania na żądanie biskupa ordynariusza.

Sekretarz prowadził protokoły z posiedzeń Kolegium, załatwiał sprawy ogłoszeń parafialnych, był głównym współpracownikiem naczelnego duszpasterza.

Wszelkie uchwały zapadały większością głosów. Obowiązywały po zaaprobowaniu ich przez władzę diecezjalną. Do niej należała też kwestia zapewnienia środków materialnych dla potrzeb Duszpasterstwa Akademickiego, jak i uposażenie księży - duszpasterzy akademickich, o ile by nie mieli zapewnionych środków z pracy duszpasterskiej w parafiach.

Kolejny rok pracy duszpasterskiej 1958/1959, przeżywany był w Duszpasterstwie Akademickim pod hasłem: „Komunia święta pierwszopiątkowa i co niedzielna"; nie przyniósł większych zmian w formach i organizacji Duszpasterstwa. Grono duszpasterzy nie uległo zmianie, ks. Gulbinowicz nadal stał na jego czele.

Duszpasterstwo Akademickie w Białymstoku korzystało przede wszystkim z obu świątyń parafii farnej. Sekretariat Duszpasterstwa znajdował się przy kościele św. Rocha, ale frekwencja była tam nieco niższa. Codziennie duszpasterza akademickiego przy tym kościele odwiedzało od 8 do 12 osób.

16 października 1958 roku zostało odprawione nabożeństwo żałobne za zmarłego papieża Piusa XII i wygłoszona do młodzieży akademickich prelekcja na temat dziejów i roli papiestwa. 2 listopada nabożeństwo żałobne za zmarłych i pomordowanych celebrował bp Suszyński.

W grudniu 1958 roku, w ramach przygotowań przed uroczystością Niepokalanego Poczęcia, odprawione zostało triduum ku czci Maryi Niepokalanej.

Pierwszą serię wielkopostnych rekolekcji (1-5 marca 1959) poprowadził ks. Witold Ostrowski, drugą (5-8 marca 1959) ks. Zdzisław Weizner z Częstochowy.

W okresie sesji wiosennej odprawione zostały trzy Msze św. w intencji pomyślnie zdanych egzaminów. 
Tak, jak w minionym roku, również w maju 1959 roku, z udziałem bp. Suszyńskiego, zostały odprawione Msze św. absolwentów dla studentów Akademii Medycznej i Studium Nauczycielskiego.

10 maja 1959 roku około 100-osobowa grupa studentów uczestniczyła w ogólnopolskiej pielgrzymce akademickiej na Jasną Górę. Tydzień później w białostockiej prokatedrze zostały odnowione Śluby Jasnogórskie.

Istniejący od października 1956 roku przy Akademii Medycznej Akademicki Klub Katolicki prowadził ożywioną działalność wśród młodzieży. Posiadał swój lokal, w nim biblioteczkę z zakresu etyki lekarskiej, nauk społecznych, ascetyki i beletrystyki katolickiej. Klub urządzał spotkania, dyskusje, czy referaty. Istniały cztery sekcje w ramach Klubu: filozoficzna, etyki lekarza, literacko-artystyczna i charytatywna. W maju 1959 roku na posiedzeniu Rady Wydziału Akademii Medycznej Klub został rozwiązany. Artykuł na temat Klubu ukazał się w "Argumentach" ${ }^{\prime 35}$.

W roku akademickim 1958/1959 ze względu na mniejsze środki pieniężne ograniczono liczbę wycieczek poza miasto. Uznano to za pewną porażkę, gdyż wycieczki dawały możliwość bliższego poznania się i zżycia się młodzieży. Udało się zorganizować obóz wakacyjny w Rucianem Nida z udziałem studentów z Białegostoku i z Katolickiego Uniwersytetu Lubelskiego. Zorganizowano tradycyjny wieczór andrzejkowy, opłatek akademicki i kulig. Wciąż pracował chór, rodziła się grupa recytatorska.

Specjalną uwagą i troską Duszpasterstwo Akademickie otoczyło kojarzące się młode małżeństwa. Starannie przygotowywano młodych ludzi do tego ważnego kroku w ich życiu, ułatwiano formalności kancelaryjne i prawne, odbywano zawsze z nupturientami kilka pogadanek religijnych przygotowujących ich do sakramentu małżeństwa ${ }^{36}$.

Zasoby materialne Duszpasterstwo Akademickie czerpało z subwencji Kurii Arcybiskupiej i z dobrowolnych ofiar wiernych zbieranych podczas Mszy św. akademickich. Sporą część zebranych środków przekazano na zapomogi najbiedniejszym studentom, na żywność, ubrania, lekarstwa. Za pozostałą sumę kupiono między innymi 40 egzemplarzy Śpiewnika Kościelnego na potrzeby Mszy św. akademickich, książki do biblioteki Duszpasterstwa oraz dwa 14-osobowe namioty na letnie akcje wypoczynkowe.

Jesienią 1959 roku nastąpiły jednak zmiany w prężnie rozwijającej się działalności Duszpasterstwa Akademickiego w Białymstoku. Na progu nowego roku akademickiego 1959/1960 ks. Henryk Gulbinowicz złożył rezygnację z dotychczas zajmowanego stanowiska głównego duszpasterza akademickiego miasta Białegostoku. A pierwszy duszpasterz akademicki w Białymstoku, ks. Witold Pietkun, 24 października 1959 roku, skazany został przez Sąd Powiatowy

\footnotetext{
$35 \quad$ „Argumenty” z 5.VIII.1959, s. 27.

36 AAB, TDA, Pismo ks. H. Gulbinowicza do ks. prałata A. Sawickiego, Sprawozdanie z działalności Duszpasterstwa Akademickiego w Białymstoku za rok akademicki 1958/1959, z 30.IX.1959 r., mps.
} 
w Białymstoku na 1,5 roku więzienia za kazania w obronie krzyży w szkołach, życia nienarodzonych dzieci oraz za krytykę poczynań władz. Odbyła się jeszcze druga rozprawa, rewizyjna, w dniu 22 stycznia 1960 roku. Wyrok został zmniejszony do 1 roku więzienia i grzywny pieniężnej. Od 4 kwietnia 1960 roku ks. Pietkun przebywał w Zakładzie Karnym w Łodzi, następnie w Zakładzie Karnym w Barczewie, 10 grudnia 1960 roku zwolniony ${ }^{37}$.

Od początku nowego 1960 roku, po odejściu do Olsztyna ks. Gulbinowicza, pełniącym obowiązki duszpasterza akademickiego w Białymstoku został ks. dr Zygmunt Lewicki ${ }^{38}$. Rozpoczął się nowy okres w dziejach Duszpasterstwa Akademickiego w Białymstoku.

\section{Bibliografia}

Archiwum Archidiecezjalne w Białymstoku (dalej: AAB), Teczka: Duszpasterstwo Akademickie (dalej: TDA), Konferencja w sprawie organizacji pracy Duszpasterstwa Akademickiego w Białymstoku, Białystok 14.X.1955 r., mps.

AAB, TDA, Nominacja ks. W. Pietkuna na seniora Duszpasterstwa Akademickiego w Białymstoku, z dn. 12.X.1957 r.

AAB, TDA, Notatka ks. A. Sawickiego do sformułowania przydziałów.

AAB, TDA, Notatka ks. E. Kisiela, z 26.X.1956 r.

AAB, TDA, Odręczna notatka ks. A. Sawickiego.

AAB, TDA, Pismo ks. Cz. Kulikowskiego do Prymasa Polski, z 24.XI.1957 r.

AAB, TDA, Pismo ks. E. Kisiela do Kurii Arcybiskupiej w Białymstoku, z d. 13.V.1955 r.

AAB, TDA, Pismo ks. H. Gulbinowicza do ks. prałata A. Sawickiego, Sprawozdanie z działalności Duszpasterstwa Akademickiego w Białymstoku za rok akademicki 1958/1959, z 30.IX.1959 r., mps.

AAB, TDA, Pismo ks. W. Pietkuna do ks. prał. A. Sawickiego wikariusza kapitulnego w sprawie budowy ośrodka akademickiego, z 11.II.1958 r.

AAB, TDA, Pismo ks. W. Pietkuna i ks. E. Kisiela do Sekretariatu Duszpasterstwa Akademickiego w Warszawie, z 28.VI.1957 r.

AAB, TDA, Pismo ks. W. Pietkuna do Kurii Metropolitalnej w Białymstoku w sprawie Duszpasterstwa Akademickiego, z 4.III.1955 r.

AAB, TDA, Pismo ks. W. Pietkuna w sprawie sytuacji Duszpasterstwa Akademickiego do ks. prałata Wikariusza kapitulnego w Białymstoku, z 10.IX.1957 r.

AAB, TDA, Pismo ks. W. Pietkuna, Sprawozdanie z inauguracji roku akademickiego 1957/1958 do wikariusza kapitulnego ks. A. Sawickiego, z 13.X.1957 r.

T. Krahel, Ksiądz Witold Pietkun; https:/ /opoka.org.pl/biblioteka/T/TH/THO/pietkun.html (dostęp 18.V.2019 r.)

38 Świadek i nauczyciel wiary. Księdza Infułata Zygmunta Lewickiego Księga Jubileuszowa, red. T. Kasabuła, A. Szot, Białystok 2010, s. 121-135. 
AAB, TDA, Pismo Kurii Biskupiej w Białymstoku do księży proboszczów i rektorów, z 27.XI.1955 r.

AAB, TDA, Pismo Prymasa Polski kard. Stefana Wyszyńskiego do ks. Cz. Kulikowskiego, z 9.XII.1957 r.

AAB, TDA, Pismo wikariusza kapitulnego do ks. W. Pietkuna, z dn. 18.XII.1956 r.

AAB, TDA, Porządek konferencji Duszpasterstwa Akademickiego pod przewodnictwem wikariusza kapitulnego ks. prałata Adama Sawickiego, 14.X.1955 r.

AAB, TDA, Regulamin Duszpasterstwa Akademickiego w Białymstoku (projekt) ułożony na polecenie przewielebnego ks. prałata Adama Sawickiego wikariusza kapitulnego, 19.XII.1955 r.

AAB, TDA, Regulamin Komisji Episkopatu Polski Duszpasterstwa Akademickiego, Warszawa 24.XI.1967 r., mps.

AAB, TDA, Sprawozdanie ks. Pietkuna przesłane do ks. prałata A. Sawickiego wikariusza kapitulnego z działalności Duszpasterstwa Akademickiego w Białymstoku za rok akademicki 1957/1958, z 30.IX.1958 r.

AAB, TDA, Sprawozdanie ks. W. Pietkuna o sytuacji na bieżący rok pracy w Duszpasterstwie Akademickim, Białystok 23.XI.1956 r.

AAB, TDA, Sprawy organizacyjne Duszpasterskiego Ośrodka, Sprawozdanie z konferencji Kolegium Duszpasterstwa Akademickiego, z 7.X.1955 r.

AAB, TDA, Wskazania Ogólnopolskiej Konferencji Duszpasterzy Akademickich, Warszawa 26.IX.1957, z 28.IX.1957 r.

AAB, TDA, Wytyczne dla duszpasterza akademickiego przyjęte na Konferencji Episkopatu w Krakowie 9 maja 1953 r., mps.

AAB, TDA, Wytyczne pracy Duszpasterstwa Akademickiego w Białymstoku na rok akademicki 1958/1959, z 10.X.1958 r.

AAB, TDA, Załącznik do listu ks. Cz. Kulikowskiego do Prymasa Polski, Sprawa budowy ośrodka Duszpasterstwa Akademickiego w Białymstoku, z 24.XI.1957 r.

Bogaczewicz S. A., Jarkiewicz K., Duszpasterstwo akademickie w Polsce po II wojnie światowej, „Biuletyn Instytutu Pamięci Narodowej” 2001, nr 10.

Danilecki T., Witold Pietkun, [w:] Encyklopedia Solidarności; dostęp 18.V.2019 r., http://www.encysol.pl/wiki/Witold_Pietkun

Krahel T., Ksiądz Witold Pietkun; https://opoka.org.pl/biblioteka/T/TH/THO/pietkun.html (dostęp 18.V.2019 r.)

Krahel T., Przez Kozielsk i Monte Cassino - ks. Czesław Kulikowski, „W Służbie Miłosierdzia" 2005, nr 3.

"Oaza wolności". Duszpasterstwo akademickie w latach siedemdziesiatych XX w. Materiały pokonferencyjne, red. M. Marcinkiewicz, Szczecin 2011.

Świadek i nauczyciel wiary. Księdza Infułata Zygmunta Lewickiego Księga Jubileuszowa, red. T. Kasabuła, A. Szot, Białystok 2010.

Wołosiuk L., A kościół trwa. Rozmowy z Kardynałem Gulbinowiczem, Wrocław 2000, s. $119-124$. 